\title{
ISOLASI, IDENTIFIKASI DAN PRESENTASI IKAN LELE DUMBO (Clarias gariepinus) YANG TERINFEKSI BAKTERI Aeromonas hydrophila YANG DIPELIHARA DI KERAMBA JARING APUNG DI BOZEM MORO KREMBANGAN, SURABAYA
}

\section{Isolation, Identification and The Presentage of African Catfish (Clarias gariepinus) on Bakterial Aeromonas hydrophila in Pond Cage in Bozem Moro Krembangan, Surabaya.}

\author{
Yudha Teguh Prayogi ${ }^{1 *}$, Rahayu Kusdarwati ${ }^{2}$ dan Kismiyati ${ }^{2}$. \\ ${ }^{1}$ Program Studi Budidaya Perairan, Fakultas Perikanan dan Kelautan, Universitas Airlangga, Surabaya \\ ${ }^{2}$ Departemen Manajemen Kesehatan Ikan dan Budidaya Perairan, Fakultas Perikanan dan Kelautan, Universitas \\ Airlangga, Surabaya \\ *yudha-t-p-11@fpk.unair.ac.id
}

\begin{abstract}
Abstrak
Ikan lele dumbo (Clarias gariepinus) merupakan ikan perairan tawar yang banyak dibudidayakan di Indonesia. Meningkatnya permintaan pasar domestik serta peluang ekspor ke beberapa negara, berdampak pula pada semakin meningkatkan minat pengusaha dan pengembangan dari teknologi budidaya intensif pada ikan ini (Masnuri, 2007). Ketersediaan ikan lele dumbo masih belum mencukupi permintaan pasar, salah satu penyebabnya adalah tingginya mortalitas ikan lele dumbo yang terinfeksi bakteri Aeromonas hydrophila.

Aeromonas hydrophila adalah bakteri penyebab penyakit Motile Aeromonas Septicemia (MAS) yang menyerang beberapa jenis ikan air tawar. Penyakit ini merupakan masalah serius pada usaha budidaya baik budidaya intensif maupun tradisional. Penyakit tersebut di Asia Tenggara, pertama kali terjadi di Jawa Barat pada tahun 1980 yang menyebabkan kematian sebanyak 82,2 ton ikan air tawar dalam sebulan, sementara di Jawa Tengah tahun 1984, sebanyak 1,6 ton ikan lele mati (Angka, 2001).

Penelitian ini bertujuan untuk mengetahui identifikasi dan persentasi bakteri Aeromonas hydrophila pada ikan lele dumbo yang dibudidayakan di bozem Moro Krembangan, Surabaya, Jawa Timur. Metode Penelitian ini adalah metode survey. Parameter utama yang diamati dalam penelitian ini adalah identifikasi dan persentasi bakteri Aeromonas hydrophila pada ikan lele dumbo yang dibudidayakan di bozem Moro Krembangan, Surabaya, Jawa Timur. Sedangkan parameter penunjang dalam penelitian yang dilakukan yaitu nilai kualitas air yang meliputi $\mathrm{pH}$, temperatur, ammonia dan Oksigen terlarut yang diukur selama kegiatan pengambilan sampel dilakukan.

Hasil penelitian menunjukkan bahwa dari 20 sampel yang diambil dari 2 keramba, 19 ekor ikan positif terinfeksi Aeromonas hydrophila. Nilai persentasi Aeromonas hydrophila yang menginfeksi ikan lele dumbo di Moro Krembangan, Surabaya, Jawa Timur yaitu sebesar $95 \%$.
\end{abstract}

Keywords: Isolasi, Identifikasi, Persentasi dan Aeromonas hydrophila

Abstract

African catfish (Clarias gariepinus) is one of the fresh waters widely cultivated in indonesia.Increased demand the domestic market and opportunities exports to some countries, impacted on the interest businessmen and to develop technology cultivation intensive with this fish (Masnuri, 2007). The availability of African catfish (Clarias gariepinus) still not enough to with the market demands, one of the causes is high mortalitas African catfish (Clarias gariepinus) infected bacteria Aeromonas hydrophila.

Bacteria Aeromonas hydrophila is the cause of a disease Motile Aeromonas Septicemia (MAS) which attacks some species to fresh-water fish.This disease was a serious problem in the business of cultivation intensive and traditional. The disease in southeast asia, first time happened in west java in 1980 that causes the death 82,2 tonnes of fresh water in a month, while in central java 1984, as many as 1.6 tons catfishes dead (Angka, 2001).

This research aims to learn about identification and the prevalence of bakteria Aeromonas hydrophila on african catfish in pond cage at bozem Moro Krembangan, East Java. The research that used was survey method. The main parameters have been observed involve both identification and the prevalence of bakteria Aeromonas hydrophila on african catfish in pond cage at bozem Moro Krembangan, East Java. The supporting parameter of water quality include temperature, dissolved oxygen, $\mathrm{NH} 3$, and $\mathrm{pH}$ which were measured during the research followed by observation. 
The research result shows that were 20 samples taken from 2 location, 19 fishes positive infected bakteria Aeromonas hydrophila The prevalence of bakteria Aeromonas hydrophila infecting african catfush, that $95 \%$.

Keywords: Isolasi, Identifikasi, Prevalensi dan Aeromonas hydrophila

\section{PENDAHULUAN}

Kota Surabaya memiliki sistem kolam penampung air yang memiliki fungsi sama dengan waduk yaitu Bozem. Bozem ini diantaranya Bozem Moro Krembangan, Kalidami, Bratang, Rungkut Industri, Wonorejo, Kedurus dan Jurang Kuping. Ekosistem bozem dibangun dikarenakan Surabaya merupakan kota yang rawan banjir dengan kurangnya daerah resapan yang berkurang. Hal ini disebabkan oleh pembangunan di Kota Surabaya yang berkembang dengan pesat. Secara umum bozem dibangun tanpa memotong sungai. Secara umum bozem ini biasanya oleh masyarakat dimanfaatkan untuk pengendali dan penyimpan air. Selain fungsi tersebut masyarakat juga ada yang memanfaatkan sebagai budidaya ikan dan pengairan sawah (Badan Perencanaan dan Pembangunan Kota Surabaya, 2010).

Penyakit ikan akibat serangan bakteri patogen (Bacterial disease) merupakan salah satu permasalahan serius bagi pembudidaya ikan lele, karena hal tersebut berpotensi menimbulkan kerugian yang tidak sedikit bagi pembudidaya ikan. Serangan penyakit bakterial dapat mengakibatkan kematian hingga $50-100 \%$, bahkan dapat menurunkan kualitas daging ikan yang terinfeksi karena adanya luka atau borok, sehingga tidak disukai konsumen (Supriyadi dan Taufik, 1981). Bakteri Aeromonas hydrophila sangat mempengaruhi kegiatan usaha budidaya ikan air tawar dan seringkali dapat menimbulkan wabah penyakit dengan tingkat kematian yang tinggi $80-100 \%$ dalam kurun waktu 1-2 minggu (Lukistyowati dan Kurniasih, 2012).

\section{Bakteri Aeromonas hydrophila} adalah agen penyebab penyakit Motile Aeromonas Septicemia (MAS) yang menyerang beberapa jenis ikan air tawar. Penyakit ini merupakan masalah serius pa- da kegiatan usaha budidaya baik budidaya secara intensif maupun tradisional. Penyakit ini di Asia Tenggara, pertama kali terjadi di wilayah Jawa Barat pada tahun 1980 yang menyebabkan kematian sebesar 82,2 ton ikan air tawar dalam sebulan, sementara di wilayah Jawa Tengah tahun 1984, sebanyak 1,6 ton ikan lele mati (Angka, 2001).

\section{METODOLOGI \\ Waktu dan Tempat}

Penelitian dilaksanakan pada 31 Agustus 2015 di Kawasan Bozem Moro Krembangan, Surabaya dan laboraturium Balai Karantina Ikan Kelas 1 Juanda Surabaya.

\section{Materi Penelitian}

Peralatan Penelitian

Materi penelitian yang digunakan terdiri dari bahan dan alat penelitian. Alat yang digunakan dalam penelitian ini adalah serok, seser, ember, baskom, nampan bedah, nampan plastik, autoklaf, selotip, tabung reaksi, pinset, aluminum foil, bunsen, cawan petri, jarum ose, timbangan analitik, gelas ukur, kapas, mikropipet, ring, mikroskop cahaya, object glass, hot plate stirer, kantong plastik, thermometer, pH meter, DO tes kit dan ammonia tes kit.

\section{Bahan Penelitian}

Bahan penelitian yang digunakan dalam penelitian ini adalah ikan sampel berupa ikan lele dari daerah Bozem Moro Krembangan, Surabaya, akuades steril, spirtus, alkohol 70\%, media selektif TSA (Triptic Soy Agar) dan Safranin.

\section{Metode Penelitian}

Penelitian ini menggunakan metode survey melalui pengambilan sampel pada lokasi secara langsung untuk mengidentifikasi Aeromonas hydrophila pada ikan 
lele dumbo (Clarias gariepinus), dengan tujuan untuk membuat deskripsi, gambaran secara sistematis, faktual dan akurat mengenai fakta, sifat serta hubungan antara fenomena yang diselidiki (Nazir, 1998).

\section{Prosedur Kerja \\ Pengambilan sampel}

Ikan lele yang diambil untuk sampel adalah ikan lele konsumsi dengan ukuran $10-15 \mathrm{~cm}$ yang berusia 2-3 bulan dengan berat 100-110 gram. Jumlah keramba yang digunakan untuk pengambilan sampel berjumlah dua keramba, total populasi ikan lele 400 ekor, dalam satu keramba terdapat popoulasi 200 ekor dan akan diambil sampel 5\% dari populasi yaitu sebanyak 20 ekor dari total populasi ikan atau 10 ekor untuk tiap keramba. Pengambilan sampel minimal 5-10\% dari jumlah total populasi (Stasiun Karantina Ikan Kelas I Hang Nadim Batam, 2011).

\section{Sterilisasi Alat}

Tahap awal dari penelitian ini adalah adalah sterilisasi. Peralatan seperti pinset, ose dan object glass sebelum digunakan terlebih dahulu disemprot alkohol $70 \%$ kemudian dilakukan pembakaran secara langsung sampai peralatan tersebut pijar dan untuk object glass dan cover glass cukup didekatkan dengan api selama beberapa detik. Untuk cawan petri disterilisasi dicuci bersih terlebih dahulu, kemudian di kemas di dalam kertas dan di masukkan ke autoclave pada suhu $121^{\circ} \mathrm{C}$ dengan tekanan $1 \mathrm{~atm}$ selama $10-15$ menit (Waluyo,2010).

\section{Isolasi Bakteri pada Ikan Lele dumbo (Clarias gariepinus)}

Bakteri diisolasi menggunakan jarum ose kemudian ditanam pada media TSA (Triptic Soy Agar) dan diinkubasi pada suhu $25^{\circ} \mathrm{C}$ selama $18-24$ jam (Sholikhah, 2009). Pengujian isolate dilakukan menggunakan mikroskop dengan pembesaran 1000 kali setelah dilakukan pewarnaan Gram pada isolate. Pengamatan mikroskop menggunakan tambahan minyak emersi dan kemudian mengamati dibawah mikroskop 1000 kali untuk melihat morfologi jenis bakteri.

\section{Identifikasi Bakteri Aeromonas hydrophila pada Ikan Lele dumbo (Clarias gariepinus)}

Identifikasi bakteri dilakukan dengan uji makroskopis, uji mikroskopis, uji pewarnaan Gram dan uji biokimia. Pengamatan uji makroskopis sampel ikan lele meliputi ukuran, pigmentasi dan bentuk yang dilihat dari dalam, samping dan atas. Uji mikroskopis dilakukan dengan pewarnaan Gram dengan mengamati warna dan bentuk bakteri serta dilakukan juga uji biokimia. Uji biokimia diantaranya uji Motil, Uji indol, Uji O/F dan uji $\mathrm{H} 2 \mathrm{~S}$.

Salah satu teknik pewarnaan diferensial yang paling baik dan paling luas digunakan untuk bakteri ialah pewarnaan Gram. Pewarnaan gram bertujuan untuk mengidentifikasikan bakteri baik mengenai bentuknya maupun sifat-sifat morfologinya. Dengan kata lain untuk memperlihatkan sel mikroba. Pewarnaan Gram merupakan salah satu metode pewarnaan ganda yang digunakan sebagai dasar pengamatan dan awal dari identifikasi bakteri. Pewarnaan bertujuan untuk memperjelas sel bakteri dengan menempelkan zat warna ke permukaan sel bakteri. Pada zat warna basah bagian yang berperan menempelkan warna disebut klorofor bermuatan positif. Sedangkan zat warna asam yang berperan memiliki muatan negative (Dwidjoseputro, 1998). Selanjutnya uji biokimia, Bakteri dinyatakan sebagai Aeromonas hydrophilla jika memenuhi kriteria sebagai berikut: pewarnaan gram negatif batang pendek, uji Motil, Uji indol, Uji O/F dan uji H2S (Jeinie dkk, 2014).

\section{Menghitung Prevalensi Infeksi Bakteri Aeromonas hydrophila}

Cara menghitung prevalensi infeksi Aeromonas hydrophila pada ikan dapat 
dilihat pada rumus berikut (Williams and Williams, 1996) :

Prevalensi bakteri Aeromonas hydrophila $=\underline{\text { Jumlah ikan yang terinfeksi } \mathrm{x} 100 \%}$ Jumlah sampel ikan

\section{HASIL DAN PEMBAHASAN Identifikasi Aeromonas hydrophila} Identifikasi Aeromonas hydrophila dilakukan dengan melihat secara makroskopis dan mikroskopis. Pengamatan makroskopis meliputi bentuk dan warna koloni Aeromonas hydrophila dan pengamatan secara mikroskopis meliputi bentuk pada pewarnaan Gram, bentuk bakteri batang pendek dengan menggunakan mikroskop perbesaran 1000 kali.

Adapun uji mikroskopis yang dilakukan dimulai dengan langkah: sampel ikan lele, pada bagian yang diduga terkandung bakteri dilekatkan jarum ose dengan kondisi selalu dekat dengan api, kemudian ose yang mengandung bakteri distreaking pada media agar TSA (Triptic Soy Agar) dan diinkubasi pada suhu $25^{\circ} \mathrm{C}$ selama 18-24 jam. Kemudian media yang ditumbuhi bakteri diambil dengan jarum ose dan ditempelkan pada object glass yang sudah ditetesi dengan safranin lalu diamati di bawah mikroskop dengan pembesaran 1000 kali. Yang kemudian dilanjutkan uji biokimia.

\section{Prevalensi Aeromonas hydrophila}

\begin{tabular}{|c|c|c|c|c|}
\hline Lokasi & $\begin{array}{l}\text { Jumlah } \\
\text { Sampel } \\
\text { yang } \\
\text { diambil } \\
\text { (ekor) }\end{array}$ & $\begin{array}{l}\text { Jumlah Ikan } \\
\text { yang } \\
\text { terinfeksi } \\
\text { Aeromonas } \\
\text { hydrophila } \\
\text { (ekor) }\end{array}$ & $\begin{array}{l}\text { Pre } \\
\text { vale } \\
\text { nsi } \\
(\%)\end{array}$ \\
\cline { 2 - 4 } A & 10 & 9 & 1 & 90 \\
\hline B & 10 & 10 & 0 & 100 \\
\hline Jumlah & 20 & 19 & 1 & 95 \\
\hline
\end{tabular}

Prevalensi merupakan persentase ikan yang terinfeksi dibandingkan dengan seluruh ikan sampel yang diperiksa (Williams and Williams, 1996). Data hasil penghitungan prevalensi bakteri Aeromonas hydrophila.

\section{Kualitas Air}

\begin{tabular}{|c|c|l|c|c|}
\hline Lokasi & $\mathrm{pH}$ & $\mathrm{DO}$ & Suhu & Amonia \\
\hline $\mathrm{A}$ & 6 & $4 \mathrm{ppm}$ & $30^{\circ} \mathrm{C}$ & $1 \mathrm{ppm}$ \\
\hline $\mathrm{B}$ & 6 & $4 \mathrm{ppm}$ & $30^{\circ} \mathrm{C}$ & $1 \mathrm{ppm}$ \\
\hline
\end{tabular}

Pada penelitian ini didapatkan kisaran nilai kualitas air yaitu: suhu $30^{\circ} \mathrm{C}$, DO 4 ppm, pH 6 dan amonia 1 ppm. Vedca (2009) menyatakan bahwa nilai kualitas air yang optimal untuk pertumbuhan ikan yaitu: suhu air $28-32^{\circ} \mathrm{C}$. Kandungan DO di dalam perairan agar pertumbuhan ikan ideal tidak kurang dari 2 ppm, $\mathrm{pH}$ 6,5-8,5 dan kandungan amonia kurang dari $1 \mathrm{ppm}$. Nilai Kualitas air ini merupakan nilai yang optimum untuk budidaya ikan lele dumbo (Clarias gariepinus) kecuali $\mathrm{pH}$ dan amonia.

\section{Pembahasan}

Salah satu jenis penyakit yang sering dijumpai pada ikan budidaya adalah penyakit bakterial yang disebabkan oleh bakteri Aeromonas hydrophilla. Agen bakteri patogen ini merupakan penyebab penyakit "Motil Aeromonas Septicemia" (MAS), terutama untuk jenis ikan air tawar di perairan tropis (Rahmaningsih, 2012). Bakteri Aeromonas hydrophila merupakan salah satu bakteri penyebab penyakit berbahaya pada budidaya ikan air tawar. Bakteri tersebut banyak menyerang ikan lele yang merupakan salah satu komoditas unggulan perairan tawar dan dapat menginfeksi ikan pada semua ukuran yang dapat menyebabkan kematian hingga mencapai persentase $80 \%$, sehingga mengakibatkan kerugian yang sangat besar baik dalam usaha budidaya ikan air tawar (Sanoesi, 2008).

Aeromonas hydrophila mempunyai bentuk batang pendek, berdiameter 0,3$1,0 \mu \mathrm{m}$, rantai pendek, Gram negatif, bergerak dengan menggunakan single po-

Diterima/submitted: 28 Desember 2015

Disetujui/accepted: 19 Juni 2016 
lar flagellum, fakultatif anaerob, fermentatif, suhu optimum $22-28^{\circ} \mathrm{C}$ tapi menghasilkan asam dan juga gas, oksidase positif dan katalase positif, urease negatif, uji gelatin positif, reduksi nitrat, Aeromonas hydrophila juga resisten terhadap klorin dan suhu rendah (Holt, 1994).

Bakteri Aeromonas hydrophila sering menyerang ikan air tawar. Pada ikan bakteri ini menyebabkan kerusakan pada sirip dan ekor, pendarahan pada pangkal sirip dan haemoragic septicemia, sering disebut juga Motil Aeromonas Septocemia (MAS). Penularan penyakit ini dapat melalui kontaminan air dan penularan dari ikan yang terinfeksi (Hayes, 2000).

Dari 20 sampel ikan yang diambil semuanya mengalami tanda-tanda gejala klinis awal seperti luka pada kulit juga rusaknya sirip dan ekor. Kemudian pada 19 ekor ikan organ ginjalnya mengalami pembengkakan dan hanya 1 ekor ikan yang tidak mengalami pembengkakan pada ginjalnya. Menurut Sniezko dan Axelrod (1971) serangan bakteri Aeromonas hydrophila dapat terjadi dalam 4 tingkatan sebagai berikut ini:

1. Akut merupakan septicemia yang fatal, infeksi cepat dengan ditandai pembengkakan organ dalam.

2. Sub akut dapat terlihat dengan gejala seperti luka dan pendarahan pada sisik.

3. Kronis dapat terlihat dengan gejala seperti bisul-bisul dan rusaknya kulit yang perkembangannya berlangsung lama.

4. Laten dapat terjadi dengan tidak memperlihatkan adanya gejala-gejala penyakit, namun pada organ dalam terdapat bakteri penyebab penyakit.

Salah satu permasalahan yang sering terjadi yaitu tidak stabilnya $\mathrm{pH}$ air. Hal ini tidak baik bagi kondisi ikan dikolam budidaya. Menurut Fauci (2001) bahwa bakteri Aeromonas hydrophila mampu tumbuh pada kisaran $\mathrm{pH}$ 4,7-11.

\section{KESIMPULAN DAN SARAN Kesimpulan}

Berdasarkan hasil penelitian yang telah dilakukan Ikan lele dumbo (Clarias gariepinus) yang dibudidayakan di Moro Krembangan Surabaya, Jawa Timur sebagian besar terinfeksi bakteri Aeromonas hydrophila. Prevalensi Aeromonas hydrophila yang menginfeksi ikan lele (Clarias gariepinus) di Moro Krembangan, Surabaya, Jawa Timur yaitu $95 \%$.

\section{Saran}

Berdasarkan hasil penelitian yang telah dilakukan disarankan agar dilakukan penelitian lebih lanjut mengenai tingkat patogenitas Aeromonas hydrophila sehingga diperoleh data yang dapat digunakan untuk melakukan pencegahan.

\section{DAFTAR PUSTAKA}

Angka, S.L. 2001. Stido karakteristik dan patologi Aeromonas hydrophila pada ikan lele sangkuriang. Makalah Falsafah Sains. IPB. $30 \mathrm{hlm}$.

Badan Perencanaan dan Pembangunan Kota Surabaya, 2010. Profil Keanekaragaman Hayati Kota Surabaya. Surabaya. Hal 240-241.

Dwidjoseputro. dan S. Ratna. 1998. Mikrobiologi Dasar Dalam Praktek. Jakarta, P.T Gramedia Pustaka.

Fauci, A. 2001. Pengaruh Pemberian Levamisol dan Saccharomyces cerevicae Dosis 60 ppm terhadap Gambaran Darah Ikan Mas (Cyprinus carpio) yang Diinfeksi Bakteri Aeromonas hydrophila. Bogor. Fakultas Perikanan dan Ilmu Kelautan, Institut Pertanian Bogor..

Hayes, J. 2000. Aeromonas hydrophila. Oregon State University.

Holt, J. G., N. R. Krieg., P. H. T. Sneath., J. T. Stanley. and S. T. Williams. 1994. Bergey's Manual of Determinative Bacteriology 9th Edition. Baltimore: The Williams and Wilkins Company.

Jeine, V. T., S. Hengky. and Bujung. 2014. Identifikasi Aeromonas hydrophila pada Ikan Mas (Cyprinus carpio) Di Desa Tatelu Kecamatan Dimembe Kabupaten Minahasa Utara. Buletin Sariputra Vol.1 (1). 
Nazir, M. 1998. Metodologi Penelitian. Ghalia Indonesia. Jakarta. 622 hal.

Sanoesi, E. 2008. Penggunaan Ekstrak Daun Pepaya (Carica papaya Linn) terhadap Jumlah Sel Makrofag pada Ikan Mas (Cyprinus carpio L) yang Terinfeksi Bakteri Aeromonas hydrophila. Jurnal Penelitian Perikanan, Vol 11, No. 2.

Sholikhah, H.E. 2009. Efektivitas Campuran Meniran (Phyllanthus niruri) dan Bawang Putih (Allium sativum) Dalam Pakan Untuk Pengendalian Infeksi Bakteri Aeromonas hydrophila Pada ikan lele dumbo dumbo (Clarias sp.). Departemen Budidaya Perairan Fakultas Perikanan dan Ilmu Kelautan Institut Pertanian Bogor. Bogor. 74 hal.

Sniezko SF and HR Axelrod. 1971. Diseases of Fishese. TFH Publication Ltd., Hongkong. Hlm 23-24.

Supriyadi, H dan Taufik. 1981. Identifikasi dan cara Penanggulangan Penyakit Bakterial pada Ikan Lele (Clarias batrachus). Bull Perik. I (3):447454.

Vedca, 2009. Teknologi Pengelolaan Kualitas Air. Bogor. 37 hal.

Waluyo, L. 2010. Teknik dan Metode Dasar dalam Mikrobiologi. Universitas Muhammadiyah Malang Press. Malang. Hal 19-30

Williams, E. H., Jr. and L. B. Williams. 1996. Parasites of Offshore Big Gami Fishes of Puerio and The Western Atlantic. Puerio Rico Department of Natural and Environmental Resources. San Juan, Pr. University of Puerio Rico. Pp383. 